\title{
斜め波状壁を用いた再生熱交換器の熱流動特性*
}

\author{
森 本 賢一*1, 鈴木 雄二*1, 笠木 伸 英*2
}

\section{Heat Transfer and Fluid Flow Characteristics of Recuperators with Oblique Wavy Walls}

\author{
Kenichi MORIMOTO*3, Yuji SUZUKI and Nobuhide KASAGI \\ ${ }^{* 3}$ Department of Mechanical Engineering. The University of Tokyo, \\ i-3 1 Hongo, Bunkyo ku, Tokyo, 1138656 Japan
}

\begin{abstract}
A series of direct numerical simulation in modeled counter flow heat exchangers with oblique wavy walls is made toward optimal shape design of recuperators. The effects of oblique angles and amplitudes of the wavy walls are systematically examined, and the heat transfer and pressure loss characteristics are investigated. The flow structures are drastically modified due to the counterrotating streamwise vortices induced by the wavy walls. By using optimal oblique angles and amplitude of the wavy walls, significant heat transfer enhancement is achieved with relatively-small pressure loss penalty. When thermal coupling of hot and cold fluid passages is considered, the averaged Nusselt number can be larger than that for isothermal heated condition. This is due to the dissimilarity between the velocity and thermal fields near the top and bottom walls. It is also found that the secondary flow and the associated thermal fields strongly depend on the Reynolds number.
\end{abstract}

Key Words: Recuperator, Direct Numerical Simulation, Laminar Flow, Wavy Wall, Heat Trans. fer Enhancement

\section{1. 序論}

近年, マイクロガスタービンを中核とする小型発電 装置が環境低負荷を実現する高効率分散エネルギーシ ステムとして注目を集めている. 種々のサイクル解析 を通じて早期実用化のための技術課題が検討され, 高 性能コンパクト熱交換器の開発の重要性が指摘されて いる(1)-(3).

様々な夕イプのコンパクト熱交換器(4)のなかで, カ スタービンに用いる再生熱交換器としては, 波状に折 り曲げた隔壁を重ねることで流路を構成するプライマ リー・サーフェス型熱交換器が有望視され, 実用化に 至っている(5), (6). しかし, 熱交換器内部の熱流動は流 線曲率や 2 次流れにより極めて複雑な様相を呈するた め, 伝熱・圧力損失特性の向上に寄与する熱と流れの 構造に対する基本的な知見は乏しく, 再生熱交換器の 高性能化・コンパクト化に向けた有効かつ一般性の高 い設計指針は得られていない.

\footnotetext{
* 原稿受付 2003 年 12 月 22 日.

*1 正員, 東京大学大学院工学系研究科(-113-8656 東京都文 京区本郷 7-3-1).

*2 正員, フェロー、東京大学大学院工学系研究科

E-mail : ysuzuki@ thtlab.t.u-tokyo.ac.jp
}

本研究では, 波状の隔壁を有する対向流型再生熱交 換器を対象とし, 直接数值シミュレーション (DNS) を 用いた数值解析により, 流路内の熱流動特性に対する 詳細な検討を行った。従来, 複雑形状流路内において 等温加熱条件や等熱流束条件(7), (8)などの温度境界条件 が課されることが多いが, 本研究では隣接する流路間 の温度連成を考虑した熱流動数值解析を行った．伝熱 面形状を表すパラメータとして波状壁の傾き角と振幅 に注目し, 対向する流れとの温度連成, 高温・低温場 の流路配置が伝熱・圧力損失特性に及ぼす影響を系統 的に調べた. そして伝熱・圧力損失特性向上への寄与 が大きい基本構造を把握し, 再生熱交換器の形状最適 化のための指針を得ることを目的とした.

\section{2. 計算対象}

図 1 に本研究で扱う対向流型熱交換器の基本単位 (計 算領域)を示す. $x, y, z$ 方向はそれぞれ流れ方向, 鉛直 方向, 横断方向にとる. 波状変形の流れ方向周期を $L_{x}$ とするとき, $x, y, z$ 方向に $L_{x} \times 2 \delta \times 2 \delta$ の正方形断面 直管ダクトを基準として上下壁 (上壁 : $y_{w, \text { top }}$, 下壁 : $\left.y_{w, \text { bottom }}\right)$ を次式で表される斜め波状壁とした. 


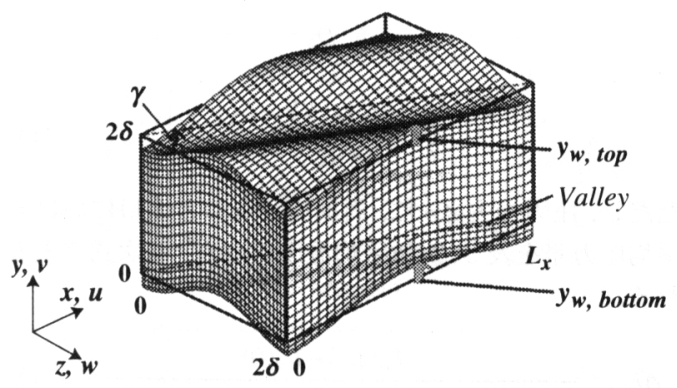

Fig. 1 Surface geometry of the passage with oblique wavy walls and computational grids with a boundary fitted coordinate system (Case 1,2).

- Case 1, 2

$$
y_{w, \text { top }}=y_{w, \text { bottom }}=-A \cos \frac{2 \pi}{L_{x}}(x-z \tan \gamma) .
$$

- Case 3, 4

$$
\left\{\begin{array}{c}
y_{w, \text { top }}=-A \cos \frac{2 \pi}{L_{x}}(x-z \tan \gamma) \\
y_{w, \text { bottom }}=-A \cos \frac{2 \pi}{L_{x}}(x+z \tan \gamma)
\end{array} .\right.
$$

ここで, $\gamma\left(=\tan ^{-1}\left(L_{x} / 2 \delta\right)\right)$ は波状変形の $z$ 軸に対する 傾き角を表す. Case 1, 2 では上下壁の谷の方向が平行 で上下壁が同一形状であり, Case 3,4 では谷の方向が $x$ 方向に対し逆に傾いた形状である. 図 2 に本研究で 想定した 4 種類の流路配置を示す.いずれの場合にも, 低温, 高温側の流路がスタガード配置となっている. 各 流路は上下の斜め波状壁と左右の平滑な側壁により囲 まれ, 厚さ無限小の隔壁を通して熱交換が行われる. Case 1, 3 (図 2a, c) の流路配置では, 左右の流路が同一 であるのに対し, Case 2,4 (図 2b,d) の流路配置では, 左右の流路が側壁に対して面対称となっている.

\section{3. 数値計算手法}

本研究では, 以下の仮定のもとで解析を行った. 1) 流体の物性值一定の非圧縮流れとする.

2) 浮力の影響, 粘性散逸による発熱は無視する.

高温・低温側各流路の作動流体は空気を仮定し (プラ ントル数: $P r=0.71)$, それぞれ流入バルク温度を一定 とした。基礎式には非圧縮ナビエ・ストークス方程式, 連続の式，および，エネルギ一方程式を用いた。流路 形状を精度良く表現するため一般座標系を導入し, 速 度場と圧力場のカップリングには SMAC 法(9)を用い た. 基本変数をコロケート配置し, エネルギー保存性 を満足する2次精度中心差分(10)により離散化を行った. 時間進行法は, 非線形項に 2 次精度アダムス・バッシュ フォース法, 粘性項に 2 次精度クランク・ニコルソン法 を用いた.

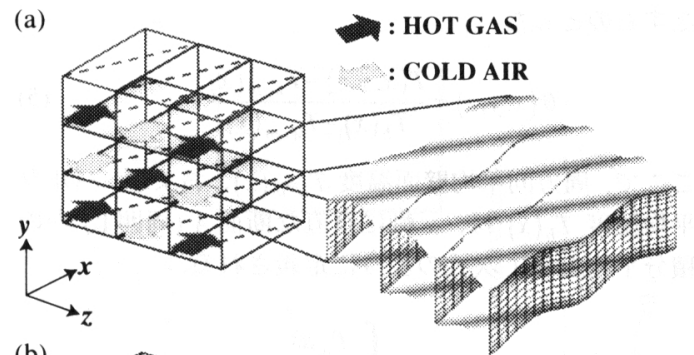

(b)

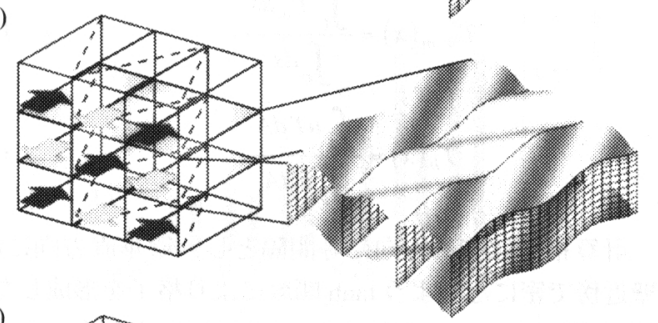

(c)

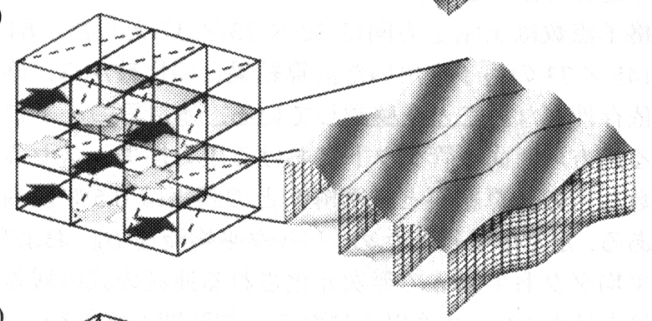

(d)

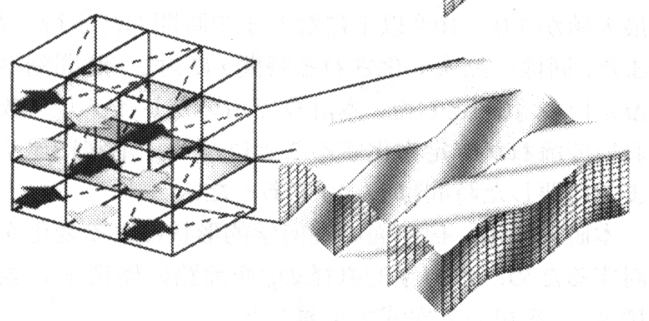

Fig. 2 Configurations of the modeled counter-flow heat exchangers. (a) Case 1, (b) Case 2, (c) Case 3, (d) Case 4.

再生熱交換器として実際に用いられるレイノルズ数 域(6)を想定し, 本計算では流れ方向バルク平均流速 $U_{b}$, 平均ダクト幅 $2 \delta$, および, 動粘性係数 $v$ で定義さ れるレイノルズ数 $\operatorname{Re}_{\delta}$ を $100 \sim 400$ とし, バルク流量 一定のもとで計算を行った。壁面上での境界条件とし て, 速度場には粘着条件を課した. 温度場には高温・低 温場の連成を考慮し, 壁面で温度と熱流束の連続条件 を課した。壁面上での温度境界条件は, 次式のように 表される.

$$
\begin{gathered}
T_{w, H o t}=T_{w, \text { Cold }}, \\
\left.\frac{\partial T}{\partial n}\right|_{w, H o t}=\left.\frac{\partial T}{\partial n}\right|_{w, \text { Cold }} .
\end{gathered}
$$

ここで, $n$ は壁面上での法線方向を表す. また, 速度場 は, 流れ方向に周期境界条件を課し, 温度場について も次式で定義される無次元温度 $\theta$ が周期境界条件を満 
たすものとした.

$$
\theta(x, y, z)=\frac{T(x, y, z)-T_{w, m}(x)}{T_{b}(x)-T_{w, m}(x)} .
$$

ここで, 周方向平均壁面温度 $T_{w, m}(x)$, および, バルク 平均温度 $T_{b}(x)$ は, $x$ 軸に垂直な断面 $A$ (周囲 $\Gamma$ ) 内の 積分平均として次式のように定義される.

$$
\begin{gathered}
T_{w, m}(x)=\frac{\int_{\Gamma} T_{w} d s}{\int_{\Gamma} d s}, \\
T_{b}(x)=\frac{\int_{A} u T d A}{\int_{A} u d A} .
\end{gathered}
$$

計算格子は流れ方向に等間隔とし, 壁垂直方向には 壁近傍で密になるよう tanh 関数により格子を形成した. 格子点数は $x, y, z$ 方向に $32 \times 73 \times 37$ とした. $64 \times$ $145 \times 73$ の格子を用いた計算結果との比較から, 格子 依存性がないことを確認している．本計算コードによ る正方形断面直管ダクトにおける圧力損失, ヌセルト 数などの計算結果と厳密解(6) との誤差は $0.5 \%$ 以内で ある. 定常解を得るため, バルク平均流速 $U_{b}$, および, 平均ダクト半幅 $\delta$ で無次元化される連続の式の残差の 最大值が $1.0 \times 10^{-6}$ 以下になるまで時間進行を行った. また, 同様に無次元化される時間 $\boldsymbol{t}$ に対し, 時間刻みは $\Delta t \sim 1.0 \times 10^{-2}$ とした. 本計算で用いたレイノルズ数に おいて流れが非定常化することはなく，定常に達する までに要した時間は $t \sim 40$ であった.

本研究では, 伝熱面の幾何学的形状による変化を検 討するため, 水力学的直径 $D_{h}$ を流路の体積 $V$ と表面 積 $S_{\text {total }}$ を用いて次式で定義した.

$$
D_{h}=\frac{4 \mathrm{~V}}{S_{\text {total }}} \text {. }
$$

また, これを用いてレイノルズ数 Re, 流れ方向 1 周期 あたりのファニングの摩擦因子 $f$, 平均壁面せん断応力 $\left\langle\tau_{w}\right\rangle$, 平均熱伝達率 $h_{m}$, 平均ヌセルト数 $\mathrm{Nu}$, および, $j / f$ 因子を以下のように定義した.

$$
\begin{gathered}
\operatorname{Re}=\frac{U_{b} D_{h}}{v}, \\
f=\frac{\left(\Delta p / L_{x}\right) D_{h}}{2 \rho U_{b}^{2}}, \\
\left\langle\tau_{w}\right\rangle=\frac{1}{S_{\text {total }}} \frac{2 D_{h}}{U_{b}} \int_{S} \frac{\partial u}{\partial n} d S, \\
h_{m}=\frac{q_{m}}{\Delta T_{l m}}=\frac{1}{S_{\text {total }} \Delta T_{l m}} \int_{S}-\left.\lambda \frac{\partial T}{\partial n}\right|_{w} d S,
\end{gathered}
$$

$$
\begin{gathered}
\mathrm{Nu}=\frac{h_{m} D_{h}}{\lambda}, \\
\frac{j}{f}=\frac{\mathrm{NuPr} r^{-1 / 3}}{f \operatorname{Re}} .
\end{gathered}
$$

ただし, 圧力損失 $\Delta p$ は, 周期流路入口と出口における 平均圧力差を表し,対数平均温度差 $\Delta T_{l m}$ は次式で表さ れる.

$$
\Delta T_{l m}=\frac{T_{h}\left(L_{x}\right)-T_{b}(0)}{\ln \left\{T_{w, m}(0)-T_{b}(0)\right\}-\ln \left\{T_{w, m}\left(L_{x}\right)-T_{b}\left(L_{x}\right)\right\}} .
$$

また, 流路形状の影響評価には, 主に $\operatorname{Re}_{\delta}=200$ の計算 を行った.

\section{4. 結果及び考察}

4.1 㑯き角の影需 図 3 に, 波状壁の振幅を $A=0.20 \delta$ で一定とし，傾き角 $\gamma$ に対する $f \operatorname{Re}$ (圧力損失)，およ び, $\left\langle\tau_{w}\right\rangle$ (摩擦抵抗) の変化を示す. 縦軸には正方形断 面直管ダクトにおける $f \operatorname{Re}$ の厳密解に対する比を示す. 圧力損失は全ケースに対して正方形ダクトに比べ上昇 し, $\gamma=45^{\circ} \sim 50^{\circ}$ において最大值をとる. 一方, 摩擦抵 抗の変化は異なり, $\gamma \sim 60^{\circ}$ のとき最大となる.これは, $\gamma$ が小さい場合, 剥離領域が拡大し, 圧力抵抗が増大す ることに起因する.

図 4 に，傾き角に対する $\mathrm{Nu}$ 数の変化を示す. 図中, 縦軸には正方形ダクトにおける各条件下での厳密解に 対する比を示す. $\mathrm{Nu}$ 数は全ケースにおいて正方形ダク 卜より增加し, $\gamma \sim 50^{\circ}$ において最大となる. 最大值は, 大きい順から Case 2, Case 1, Case 4, Case 3 である. な お, 式 (15) で定義される平均温度差の各温度連成条件 による違いは $2 \%$ 以内であり, $\mathrm{Nu}$ 数の変化量は, 平均 熱流束 $q_{m}$ の変化に支配されている. また，本計算で は, 伝熱面の波状変形に伴う面積増加分を式 (8)により 補正しているため, 熱交換器としての実質の伝熱量, 圧 力損失はさらに上昇する $\left(\gamma=50^{\circ}\right.$ で約 $10 \%, \gamma=60^{\circ}$ で 約 3\%).

一方，傾き角に対する $j / f$ 因子の変化は Case 3 を除 いて摩擦抵抗の変化と定性的にほほ一致し， $\gamma \sim 60^{\circ}$ で 最大値をとる (図 5). また, Case 2, 4 では, 壁温一定 の等温加熱条件に対しても伝熱特性が向上することが わかる. 今回計算を行った熱交換器モデルの中では, Case 2, すなわち, 上下の波状壁が同位相で変形し, か つ, 隣接する流路の波状変形が隔壁に対して面対称の 場合, $j / f$ 因子が最も大きい. 以下, Case 2 に焦点を絞っ て議論する.

4.2 振幅の影需 波状壁の傾き角を $\gamma=50^{\circ}, 60^{\circ}$ で一 定とし, 振幅 $A$ を変化させた場合の $f \operatorname{Re},\left\langle\tau_{w}\right\rangle, \mathrm{Nu}$ 数, および, $j / f$ 因子の変化の様子を図 $6 \sim 8$ に示す. $\gamma=50^{\circ}$, 
(a)

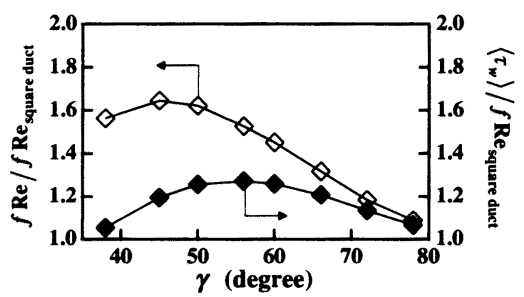

(b)

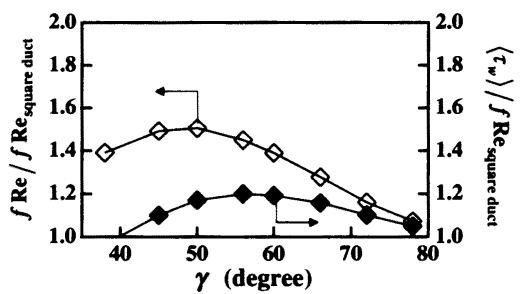

Fig. 3 Pressure loss and friction drag versus the oblique angle. (a) Case 1, 2, (b) Case 3, 4.

(a)

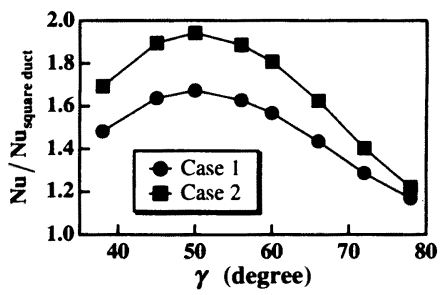

(b)

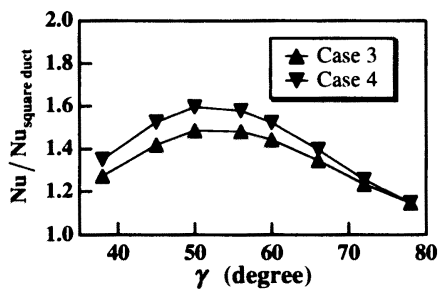

Fig. 4 Averaged Nusselt numbers versus the oblique angle. (a) Case 1, 2, (b) Case 3, 4.

(a)

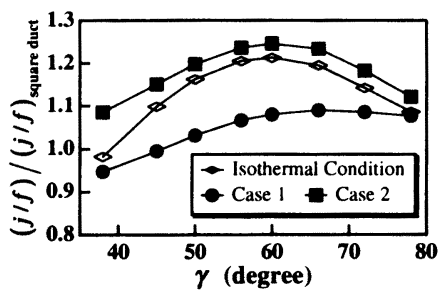

(b)

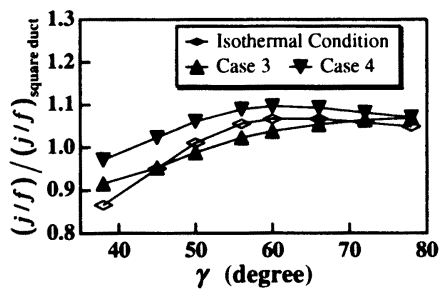

Fig. $5 j / f$ factor versus the oblique angle. (a) Case 1, 2, (b) Case 3, 4 . (a)

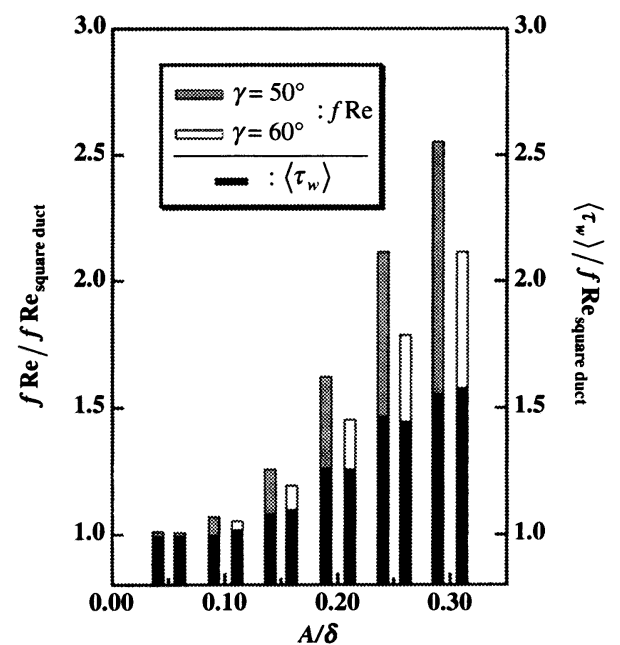

Fig. 6 Effect of wave amplitudes on pressure loss and friction drag at $\gamma=50^{\circ}, 60^{\circ}$.

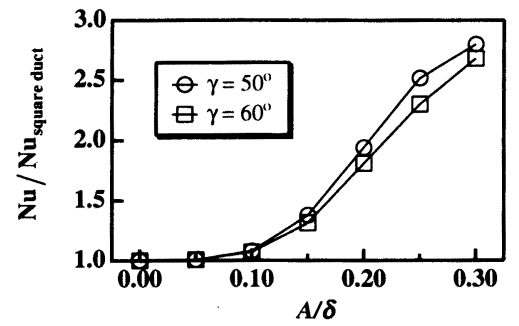

Fig. 7 Effect of wave amplitudes on the average Nusselt number.

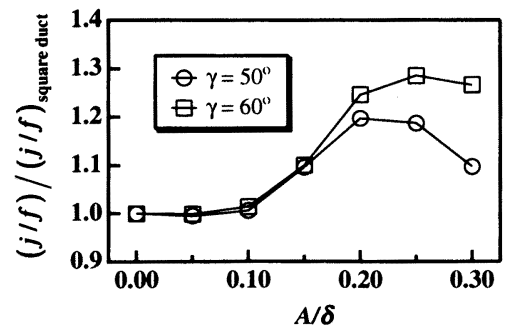

Fig. 8 Effect of wave amplitudes on $j / f$ factor.

$60^{\circ}$ において $\left\langle\tau_{w}\right\rangle$ の值はほぼ等しいのに対し, $\gamma=50^{\circ}$ では振幅の増加に伴い剥離領域が拡大し (図省略), $f \operatorname{Re}$ は增大する (図 6). 従って, $\gamma=50^{\circ}, 60^{\circ}$ で伝熱特性を 比較すると, $\gamma=50^{\circ}$ では剥離・再付着による伝熱促進 効果がより強くなるため, 全体としての熱伝達は $\gamma=$ $60^{\circ}$ の場合より大きくなると考えられる (図 7). 一方, $\mathrm{Nu}$ 数は $\gamma=50^{\circ}$ の方が大きいのに対し, $j / f$ 因子として は圧力抵抗の小さい $\gamma=60^{\circ}$ の方が大きな值をとる (図 8). 従って, j/f 因子の最適化という観点からは, 剥離を 抑制し, 圧力損失の増加を抑えることが重要であると 言える. どちらの場合でも, $j / f$ 因子は $A=0.20 \sim 0.25 \delta$ で最大值をとっており, $j / f$ 因子を最大にする適切な振幅 
(a)

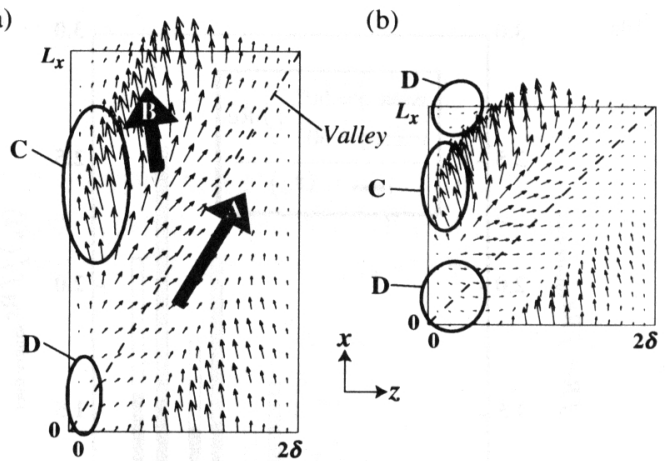

Fig. 9 Wall shear stress vectors on the bottom wall projected onto the $x$ - $z$ plane. (a) $\gamma=60^{\circ}$, (b) $\gamma=45^{\circ}$.

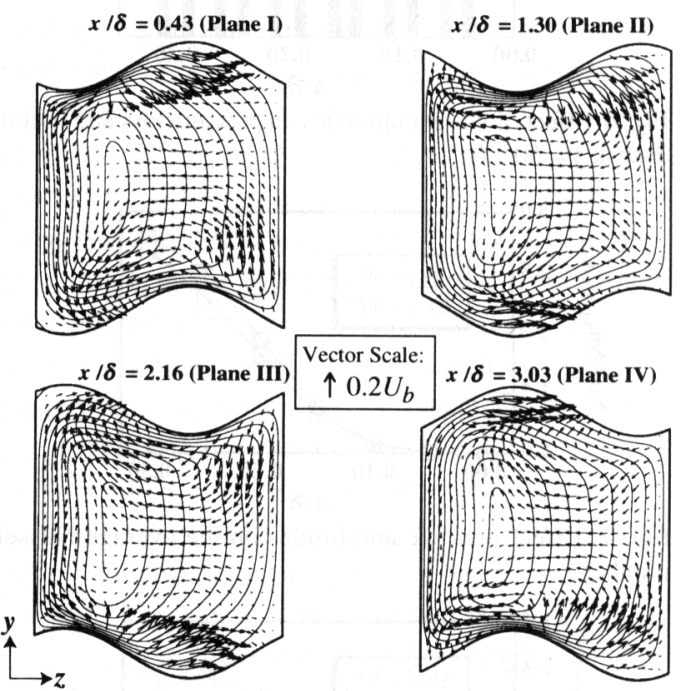

Fig. 10 Velocity vectors and iso-contours of the streamwise velocity in $y-z$ planes for $\gamma=60^{\circ}$. The contour increment is $0.2 \times U_{b}$. Refer to Fig. 11 for the streamwise positions of Plane I - IV.

が存在することがわかる.

以下，上述の平均特性に及ぼす流れ場・温度場の構 造を分析し, 斜め波状壁による熱交換器性能向上のメ カニズムを考察する.

4.3 熱流動構造の変化 図 9 に下壁面におけるせん 断応力ベクトルの $x-z$ 平面への投影図を示す. $x$ 方向の 流れが波状壁により曲げられ，谷の部分で右方向に向 う流れが生じている (図中矢印 A). 一方，山の部分で は山を越えて下流側の谷に向かう左方向への強い流れ が生じる (図中矢印 B). $\gamma=60^{\circ}$ の場合, 左壁近傍の山 の部分 (図中領域 C) で流れは壁に沿い, 剥離領域 (図 中領域 D) が小さいのに対し， $\gamma=45^{\circ}$ では山の部分で 流れが剥がれ, 大きな剥離が生じていることがわかる。 以下, $j / f$ 因子が最大となる $\gamma=60^{\circ}, A=0.20 \delta$ における 結果を示す。

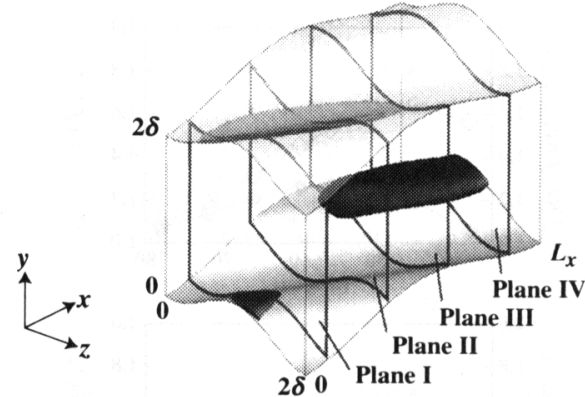

Fig. 11 Isosurfaces of the second invariant of the deformation tensor $(\mathrm{Q}<-3.0)$ at $\gamma=60^{\circ}$ : black, streamwise vorticity $\omega_{x}<0$; gray, $\omega_{x}>0$.
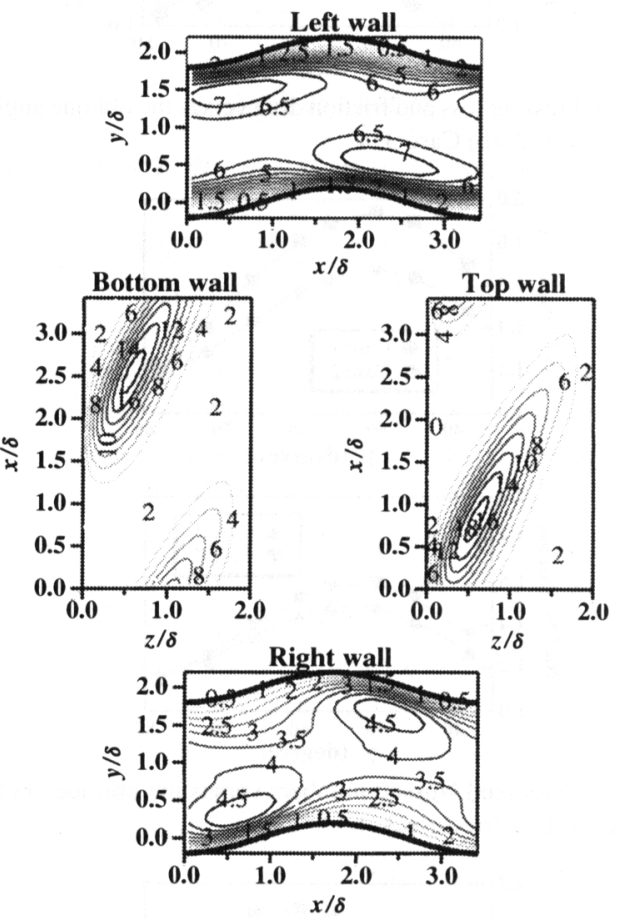

Fig. 12 Distribution of the wall shear stresses.

図 10 に $y$ - $z$ 断面内の速度ベクトル，および，流れ方 向速度の等值線を示す。上下の波状壁に沿う流れが側 壁の拘束を受けるため, 山を越えて低圧領域 (谷の部分 )に向う強い回転運動が誘起され，下壁面には反時計回 り，上壁面には時計回りの渦構造が形成される。波状 壁により誘起される渦の回転方向が上下壁で逆である ことにより, ダクト中央部には左側面に向う流れが生 じ，高流速領域が左側面側に偏る。図 11 に変形速度 テンソルの第二不変量 $(Q)$ で抽出される渦構造を示す. 流体側から見て上下の波状変形は逆方向であるため, 逆回転の渦構造が流れ方向に半周期の位相差で形成さ れている様子がわかる. 2 次流れの強度は極めて大きく, 渦構造により誘起される $y$ - $z$ 断面内速度の最大值はバル 
(a)

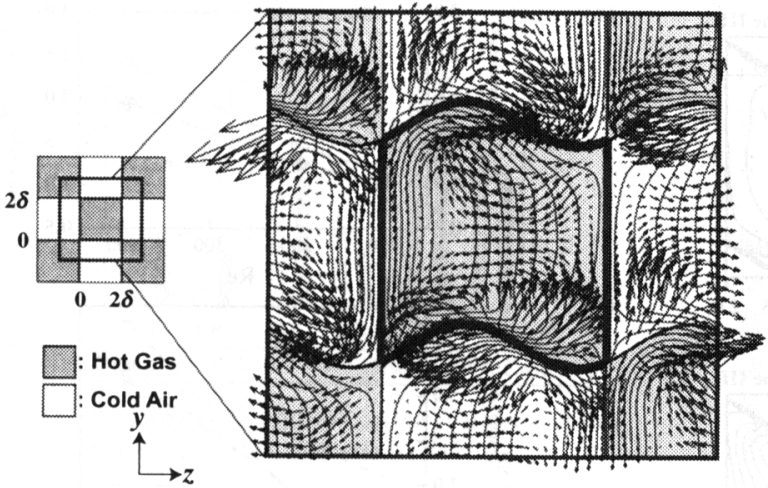

(b)

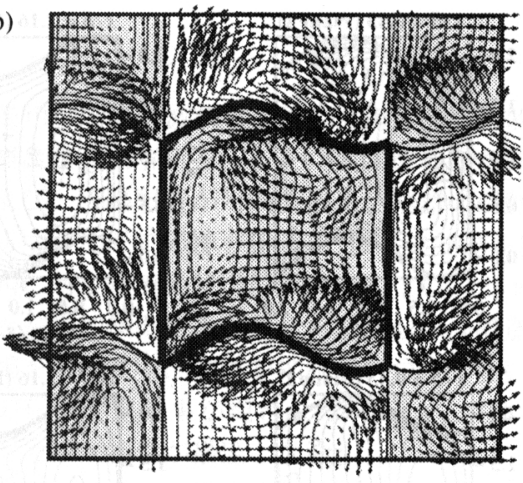

Fig. 13 Velocity vectors and iso-contours of temperature under thermal coupling condition in the $y-z$ plane at $x / \delta=3.03$ (Plane III) for $\gamma=60^{\circ}$. (a) Case 1, (b) Case 2 .
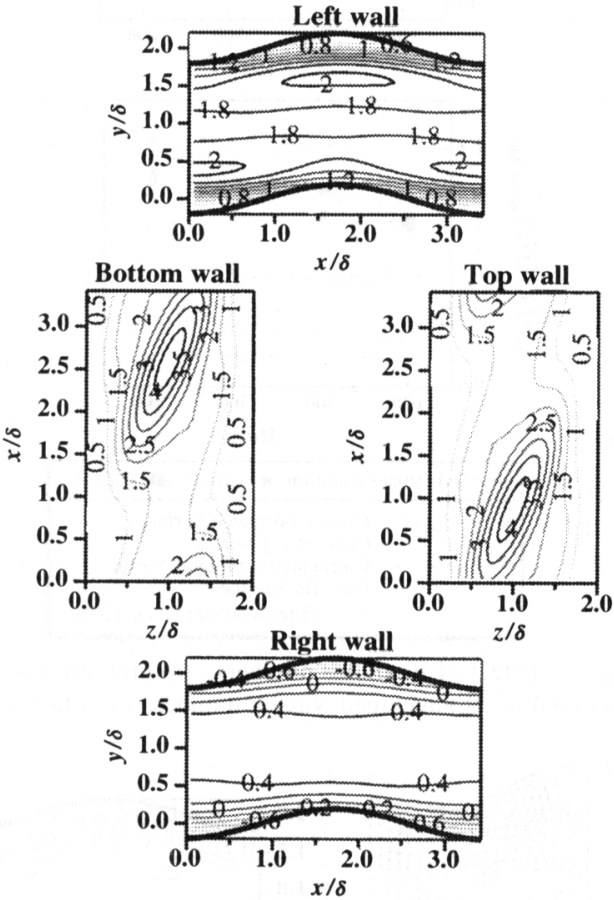

Fig. 14 Distribution of the wall heat flux under coupling condition: Case 1.

\section{ク平均流速の約 $20 \%$ に達する.}

“戝 12 に各壁面における流れ方向せん断応力の分布を 示す. 上下壁では山に沿う領域でせん断応力が大きく, 左右の側壁では広範囲にわたり比較的均一な分布とな ることがわかる.また, 高速流体がダクト左側に偏る ため左右の側面におけるせん断応力の強度は大きく異 なり, 左壁面の平均せん断応力は右側面に比べ, 約 1.7 倍の大きさとなる. 図には示さないが, 等温加熱条件 下での熱流束分布も同様であり, 左側面での熱伝達が 大きいのに対し, 流速が小さい右側面における熱伝達 は極めて小さい.
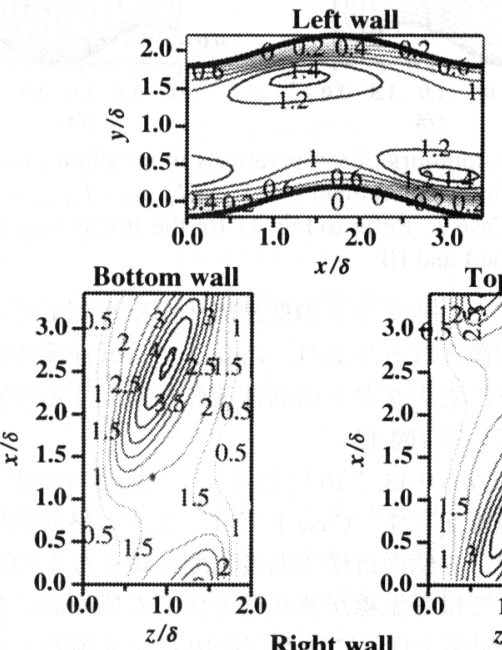

Top wall

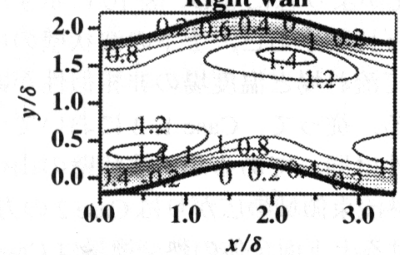

Fig. 15 Distribution of the wall heat flux under coupling condition: Case 2.

図 13 に $x / \delta=3.03$ における $y-z$ 断面内の速度ベクト ル,および, 温度場の等值線を示す.また, 図 14,15 に 図 13 の太枠線内の中央ダクトについて各温度連成条件 (Case 1,2) に対する壁面熱流束の分布を示す. Case 1 で は, 伝熱特性の良い側面同士, 伝熱特性の悪い側面同 土が隔壁を共有するため, 中央ダクトの左側面におい て著しく伝熱特性が向上する (図 14), 一方, Case 2 で は左右のダクトの流れ場が面対称であるため, 2 つの側 面では伝熱特性の悪い側, 良い側が隔壁を共有し, 左 右両側面における伝熱特性は等しくなる (図 15). Case 1 では熱輸送の乏しい低速流体に対し, 上, 下のダクト 

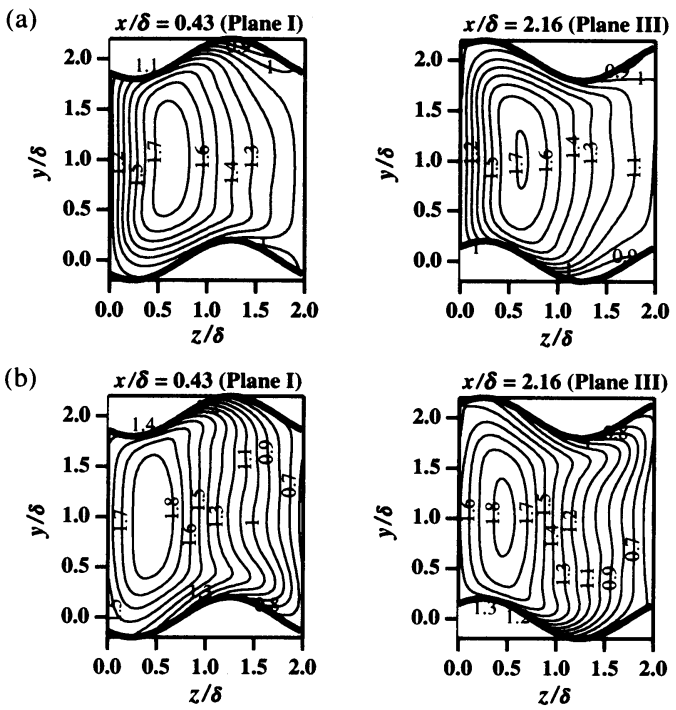

Fig. 16 Iso-contours of temperatures in $y-z$ planes for $\gamma=$ $60^{\circ}$. The contour increment is $0.1 \times\left(T_{i n, H o t}-T_{i n \text {. Cold }}\right)$. (a) Case 1, (b) Case 2. Refer to Fig. 11 for the streamwise positions of Plane I and III.

の高速流体と右側ダクトの低速流体が壁を隔てて対向 する流路配置となっており, Case 2 では低速流体の周 囲を上, 下, 右のダクトの高速流体が対向する流路配 置となっている (図 13).

図 16 に $x / \delta=0.43,2.16$ における $y$ - $z$ 㥪面内の連成温 度場の等值線を示す. Case 1 では, 上述の熱流動場の 連成により，右側面近傍で温度勾配が緩くなるのに対 し, Case 2 では等温線が波状壁近傍で右側面側に移動 し, 温度勾配がより急になる. 図 10 に示す流れ方向速 度の等值線と比較すると, 上下の波状壁の山から右側 面側にかけて流れ場と温度場の非相似性が顕著である ことがわかる．従って, Case 1, 2 において上下壁にお ける連成条件は同一であるが，波状壁の山付近に存在 する高壁面熱流束領域の広がりは Case 2 の方が大きく, Case 2 における上下面全体の熱交換量は Case 1 に比べ, 約 $20 \%$ 上昇する (後述，図 19). すなわち，左右両側 面全体での熱交換量は Case 1, 2 でほぼ等しく，上下の 波状壁の伝熱特性の向上が Case 2 における総伝熱量の 向上へ寄与している.

4. $4 \mathrm{Re}$ 数依存性の評価 傾き角を $\gamma=60^{\circ}$, 振幅を $A=$ $0.20 \delta$ に固定し, Re 数による熱流動特性の変化を評価 した. 図 17 に $\operatorname{Re}_{\delta}=100,200,400$ における $f \operatorname{Re},\left\langle\tau_{w}\right\rangle$, $\mathrm{Nu}$ 数, および, $j / f$ 因子の変化を示す. また，比較のた め, 既存のコンパクト再生熱交換器の性能予測例(6)を 併せて示す.本熱交換器では, $\mathrm{Re}$ 数の増加に伴い $\mathrm{Nu}$ 数 は $f \operatorname{Re},\left\langle\tau_{w}\right\rangle$ を上回る増加を示し, $j / f$ 因子は増加する. しかし, $\mathrm{Nu}$ 数, $j / f$ 因子における, Case 2 の Case 1 に対 する優位性は一旦上昇した後, 下降に転じることがわ (a)

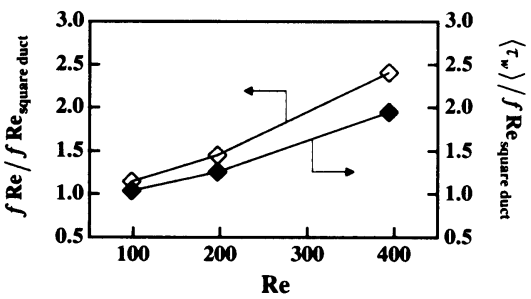

(b)

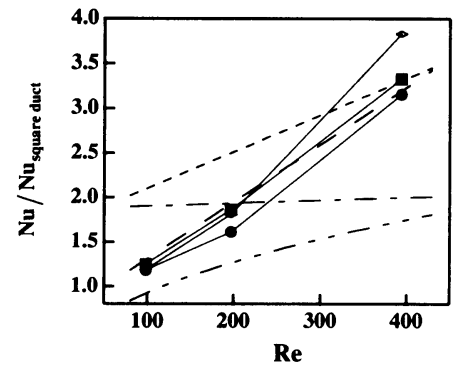

(c)

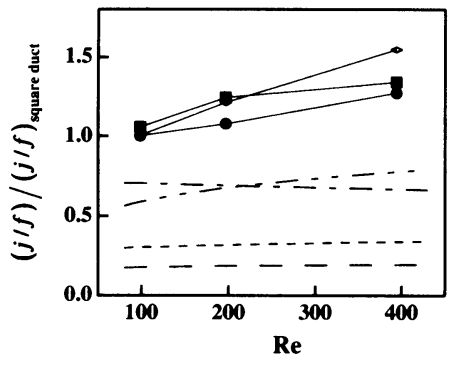

\begin{tabular}{|c|c|}
\hline - Isothermal & Condition - Case $1-$ \\
\hline $\begin{array}{l}---\overline{-} \\
\overline{-}-\overline{-}\end{array}$ & $\begin{array}{l}\text { Cross-Corrugated Surface } \\
\text { Cross-Wavy Surface } \\
\text { Corrugated Undulated Surface } \\
\text { Plate-fin Surface } \\
\quad \text { (Utriainen and Sunden [6]) }\end{array}$ \\
\hline
\end{tabular}

Fig. 17 Effect of Reynolds numbers. (a) pressure loss and friction drag, (b) averaged Nusselt number, (c) $j / f$ factor.

(a)
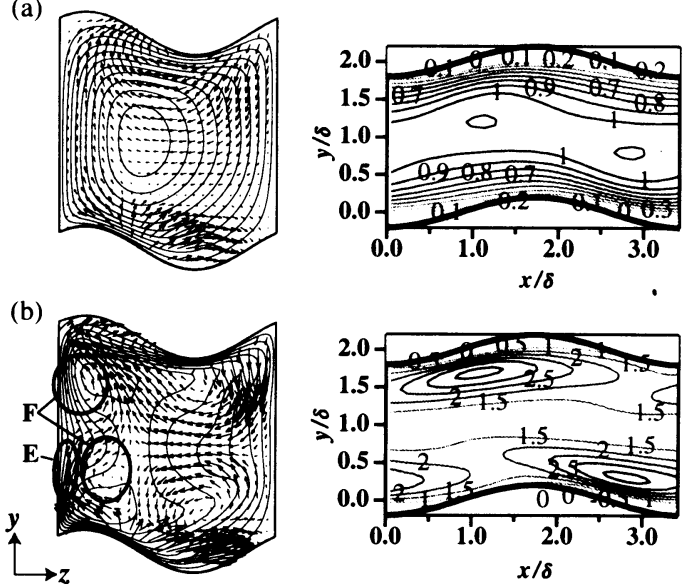

Fig. 18 Velocity vectors in the $y-z$ plane at $x / \delta=2.16$ (Plane III) and distribution of heat flux on the left wall in Case2. (a) $\operatorname{Re}_{\delta}=100,(\mathrm{~b}) \operatorname{Re}_{\delta}=400$. 


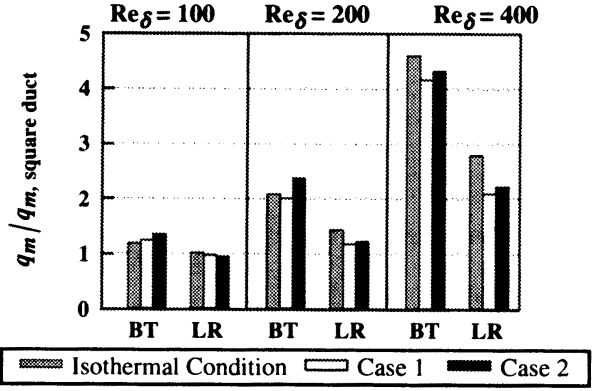

Fig. 19 Effect of Reynolds numbers on the average heat flux of bottom and top walls (BT), and side walls (LR).

かる. また, 本熱交換器は, 既存の熱交換器に比べ圧 力損失の増加が小さく,$j / f$ 因子が極めて大きい

図 18 に $\operatorname{Re}_{\delta}=100,400$ における $y$ - $z$ 断面内の速度べ クトル, および, 左側面上の壁面熱流束の分布 (Case 2) を示す. $\operatorname{Re}_{\delta}=200$ の場合 (図 15 ) と比較すると, $\mathrm{Re}_{\delta}$ $=100$ の場合は 2 次流れの強度が弱く, 波状壁が熱流動 場に及ぼす効果は小さい. 一方, $\operatorname{Re}_{\delta}=400$ の場合は波 状壁の影響が強まり, 流れの構造は大きく変化する. 左 側面と下壁の山が合流する領域 (図 9: 領域 C) で強度 の鈶直方向速度が誘起される (図中領域 E). 同時に, 上 壁においても下壁と半周期の位相差で左側面に沿う強 い流れが生じるため, 両者が衝笑する左側面中央付近 $(y / \delta=1.0)$ でダクト中央に向う流れが強まる. その結果, 上下に渦領域が形成され (図中領域 F), 左側面付近に 位置する高速流体の分布が上下に二極化する．このと き, 各温度境界条件による壁面近傍の温度分布の違い が減少し, $\operatorname{Re}_{\delta}=200$ の場合に顕著であった上下壁近 傍の熱と流れの非相似性は弱まる (図省略).

図 19 に各 Re 数における上下壁, 左右側壁全体での 平均熱流束を, 正方形断面直管ダクトに対する比で示 す. $\operatorname{Re}_{\delta}=100,200$ では, 上下壁における平均熱流束の 上昇率が Case 2 において最大であり，等温加熱条件よ りも大きい. 一方, $\operatorname{Re}_{\delta}=400$ では, 温度連成効果が 弱まり等温加熱条件が最大となる. 側壁全体の平均熱 流束の上昇率は, $\mathrm{Re}$ 数によらず等温加熱条件が最も高 い. また，各壁面の平均熱流束が総伝熱量に占める割 合は, $\operatorname{Re}$ 数によらず側壁より上下壁の方が大きく, そ の差は Re 数の增大に伴い拡大する. 従って, 上下壁に おける平均熱流束の上昇率が図 17 (b)に示した各 $\operatorname{Re}$ 数 における $\mathrm{Nu}$ 数の大小関係と対応していることがわか る.

以上より, $\operatorname{Re}_{\delta}=200$ では, $\gamma=60^{\circ}, A=0.20 \delta$ が最適 であるが, $\operatorname{Re}$ 数の変化に伴って流れの構造, 伝熱特性 も大きく変化することがわかった．熱交換器としての 応用を考えた場合, ある程度の $\operatorname{Re}$ 数範囲にわたつて最 適条件を満たすことが望ましく, その観点からは, 流 路構成のさらなる検討も必要であると考えられる.

\section{5. 結 論}

DNSを用いて斜め波状壁を用いた再生熱交換器を模 擬した層流熱流動解析を行った．波状壁の傾き角，振 幅, および, 流路配置が対向流型熱交換器の伝熱・圧 力損失特性に及ぼす影響を評価し，以下の知見を得た.

1) 傾き角に対し熱流動特性は顕著に変化し，上下の波 状壁と左右の側壁により生じる逆回転の渦構造対が 流れ場を支配する. 剥離が抑制されつつ, 強い 2 次 流れの伝熱促進効果が現われる $\gamma \sim 60^{\circ}$ において伝 熱・圧力損失特性が最適となる.

2) 振幅の増加により, 熱伝達が大幅に促進されると同 時に剥離領域が増大するため, $j / f$ 因子を最大にする 適切な振幅が存在する.

3) 対向する高温・低温流体の流路配置により伝熱特性 は有意に変化する. 伝熱特性の悪い領域の周囲に伝 熱特性の高い流体が隔壁を介して対向する配置によ り熱と流れの非相似性が増し，等温加熱条件よりも さらに熱伝達が増大する. 従って, 定量的な性能評 価を行うには温度連成を考慮することが必要である.

4) 本流路形状における熱流動特性は, レイノルズ数の 違いにより大きく変化する. しかし，本熱交換器で は圧力損失の増加が抑えられるため, 既存のコンパ クト再生熱交換器に比べ, $j / f$ 因子が極めて大きい.

本研究は, 科学技術振興事業団との間で戦略的基礎 研究推進事業の一環として契約された「資源循環・エ ネルギーミニマム型システム技術」研究領域内の「超 小型ガスタービン・高度分散エネルギーシステム」研 究の成果である. また, 文部科学省科学研究費補助金 特別研究員奖励費 (15-11654) の援助を受けた.ここに 記して謝意を表する.

\section{文献}

（1）笠木・君島, エネルギー・資源, 23-3 (2002), 183.

(2) 上地・君島・笠木, 機論 , 68-666, B (2002), 626-635.

(3) 君島・鹿園・笠木, 第22 回エネルギ一・資源学会研究発表 会講演論文集, (2003), 57-62.

(4) Kays, W. M., and London, A. L., Compact Heat Exchangers, 3rd Edition, (1984), McGraw-Hill Inc..

(5) McDonald, C. F., Applied Thermal Engineering, 20-5 (2000), 471-497.

(6) Utriainen, E., and Sunden, B., ASME J. Engineering for Gas Turbines and Power, 124-3 (2002), 550-560.

(7) Shah, R. K., and London, A. L., Advances in Heat Transfer, Supplement 1, (1978), Academic Press.

(8) Kasagi, N., Tomita, Y., and Kuroda, A., ASME J. Heat Transfer, 114-3 (1992), 598-606.

(9) Amsden, A. A., and Harlow, F. H., J. Computational Physics, 6 (1970), 322-325.

(10) 暒島 - 他 3 名, 機論, 63-614, B (1997), 3247-3254. 